\title{
Obesitas Sentral terhadap Kadar Gula Darah Postprandial pada Pegawai Laki-Laki Dewasa di Lingkungan Kerja
}

\author{
Andini Bakti Putri ${ }^{1}$, Anita ${ }^{2}$ \\ ${ }^{1}$ Fakultas Kedokteran, Universitas Lampung, Indonesia \\ ${ }^{2}$ Jurusan Keperawatan, Politeknik Kesehatan Tanjung Karang, Indonesia \\ Email: andinibaktiputri@gmail.com
}

\begin{abstract}
The Relation Between Central Obesity with Postprandial Blood Glucose on Adult Male Employees. Type 2 diabetes patients as much as $80 \%$ are overweight (obese). The obesity rate in Lampung province is $8.7 \%$. The lowest prevalence of central obesity is $2.2 \%$ in North Lampung and $35.9 \%$ is highest in Metro city. Obesity causes changes in body cells to become resistant to the hormone insulin, so that blood levels increase. The effect of it is that insulinproducing cells work harder and become gradually damaged, these are the reason that causes an increase in the number of diabetics. The purpose of this study to determine the relations of central obesity to postprandial blood glucose levels in adult male employees at Lampung University. This research used a cross-sectional approach. The sample of this research is all male employees of Lampung University with ages of 26-45 years determined by consecutive sampling. 65 respondents like to check postprandial blood glucose levels. The data were analyzed by using the Chi-Square test. Most of the respondents had abnormal postprandial blood glucose levels (67.7\%) than respondents who had normal postprandial blood glucose levels $(32.3 \%)$. Based on bivariate analysis with the Chi-square test, the relation of central obesity and postprandial blood glucose levels in male adult employees in Lampung University with a p-value of 0.001 . There is a relationship between central obesity in adult male employees and postprandial blood glucose levels at Lampung University.
\end{abstract}

Keywords: Central obesity, Postprandial blood glucose

\begin{abstract}
Abstrak: Hubungan Obesitas Sentral Terhadap Kadar Gula Darah Postprandial pada Pegawai Laki-Laki Dewasa di Lingkungan Kerja. Penderita diabetes type 2 sebanyak $80 \%$ mengalami kelebihan berat badan (obesitas). Angka obesitas di provinsi Lampung sebesar 8,7\%. Prevalensi obesitas sentral terendah 2,2\% di Lampung Utara dan tertinggi 35,9\% di kota Metro. Obesitas menyebabkan perubahan sel tubuh menjadi resisten terhadap hormon insulin, sehingga kadar darah meningkat. Dampaknya sel-sel penghasil insulin bekerja lebih keras dan menjadi rusak secara bertahap, hal inilah yang menyebabkan peningkatan jumlah penderita diabetes. Tujuan penelitian ini untuk mengetahui hubungan obesitas sentral terhadap kadar gula darah postprandial pada laki-laki dewasa di lingkungan kerja Universitas Lampung. Penelitian ini menggunakan pendekatan cross sectional. Sampel penelitian adalah seluruh pegawai laki-laki dewasa dilngkungan kerja Universitas Lampung dengan usia 26-45 tahunyang ditentukan dengan consecutive sampling, Jumlah sampel 65 responden, analisis data menggunakan ujiChi-Square. Analisis statistik menunjukkan bahwa sebagian besar responden mengalami obesitas sentral $55,4 \%$ dan memiliki kadar gula darah postprandial yang tidak normal $(\geq 140 \mathrm{mg} / \mathrm{dl})$ sebanyak $67,7 \%$. Berdasarkan analisis uji Chi-square didapatkan hubungan obesitas sentral terhadap kadar gula darah postprandial pada pegawai laki-laki dewasa di lingkungan Universitas Lampung dengan nilai $p$-value $=0,001$. Terdapat hubungan bermakna antara obesitas sentral pada pegawai laki-laki dewasa terhadap kadar gula darah postprandial di Universitas Lampung.
\end{abstract}

Kata kunci: Obesitas sentral, Kadar gula darah postprandial

\section{PENDAHULUAN}

Obesitas merupakan keadaan patologis yang terjadi karena penimbunan lemak berlebih dari yang dibutuhkan untuk berjalannya fungsi tubuh. Obesitas sentral dapat diartikan sebagai suatu kondisi kronis yang ditandai oleh kelebihan lemak tubuh disertai penumpukkan lemak viseral di perut. Kelebihan lemak di perut digunakan sebagai komponen kuncidalam penilaian obesitas sentral. Obesitas merupakan salah satu faktor resiko penyebab terjadinya penyakit degeneratif 
seperti diabetes melitus, penyakit jantung koroner, dan hipertensi (Long, et al., 2011). Di Indonesia, persoalan obesitas merupakan salah satu masalah kesehatan. Berbagai faktor berperan dalam timbulnya obesitas, tetapi yang paling penting adalah ketidakseimbangan antara masukan makanan dan aktifitas fisik. Berdasarkan data Riset Kesehatan Dasar 2013 menunjukkan peningkatan prevalensi kegemukan dari $1,4 \%$ pada tahun 2010 menjadi 7,3\% pada tahun 2013. Secara nasional, prevalensi adalah $26.6 \%$, lebih tinggi dari prevalensi pada tahun 2007 (18,8\%) (Kemenkes, 2013a). Data Riskesdas Lampung, jumlah penduduk dewasa yang mengalami obesitas di Provinsi Lampung sebanyak $8,7 \%$. Prevalensi terendah terdapat di Kabupaten Pringsewu $(3,1 \%)$ dan tertinggi di Kabupaten Lampung Utara (11,3\%). Prevalensi penduduk umur $\geq 15$ tahun yang mengalami obesitas sentral berdasarkan Kabupaten di Provinsi Lampung. Prevalensi obesitas sentral terendah di Kabupaten Lampung Utara $(2,2 \%)$ dan tertinggi di Kota Metro (35,9\%) (Kemenkes, 2013b).

Peningkatan prevalensi obesitas berhubungan dengan urbanisasi dan perubahan status ekonomi yang terjadi di negara-negara berkembang berdampak pada peningkatan prevalensi obesitas pada populasi di semua negara, termasuk di Indonesia (Soegondo, 2014). Penderita diabetes tipe 2 sebanyak $80 \%$ mengalami kelebihan berat badan atau obesitas. Kelebihan berat badan dapat menyebabkan perubahan terhadap sel-sel tubuh, sehingga menjadi resisten terhadap hormon insulin. Ketika seseorang mengalami resisten terhadap insulin, glukosa darah tidak dapat diambil oleh sel-sel tubuh secara sempurna sehingga meningkatkan kadar gula dalam darah. Sel-sel yang memproduksi insulin harus bekerja lebih keras untuk menjaga kadar gula darah dalam keadaan normal. Hal ini dapat menyebabkan sel-sel penghasil insulin rusak secara bertahap (National Diabetes Information Clearing House, 2012).

Obesitas meningkatkan pengeluaran asam lemak bebas (free fatty acid) di darah. Pelepasan asam lemak bebas oleh endotel lipoprotein lipase akibat peningkatan trigliserida serum meningkatkan elevasi lipoprotein $\beta$ sehingga menyebabkan lipolisis yang akan mengakibatkan terjadinya disfungsi reseptor insulin. Akibat dari resistensi insulin menyebabkan hiperglikemia akibat kompensasi glukoneogenesis di hati. Asam lemak bebas menurunkan utilisasi glukosa otot yang distimulasi insulin. Lipotoksisitas akibat jumlah asam lemak bebas yang meningkat menyebabkan penurunan sekresi insulin dari sel $\beta$ pankreas dan akhirnya menyebabkan kelelahan sel $\beta$ pankreas (Redinger, 2007).

Kadar gula darah postprandial (GDPP) memiliki kontribusi yang tinggi terhadap kontrol gula darah. Berdasarkan studi Whitehall, Honolulu, dan Oslo pemeriksaan GDPP dapat digunakan untuk menjadi indikator utama dalam mendeteksi dengan cepat terindikasi penyakit diabetes, dan juga dapat menghindari risiko obesitas, penyakit jantung dan pembuluh darah (Woerle, 2007). Penelitian yang dilakukan pada orang dewasa di Spanyol membuktikan bahwa kelebihan berat badan dan obesitas secara signifikan lebih tinggi pada laki-laki daripada wanita, dalam semua golongan usia yang dianalisis. Secara keseluruhan membuktikan bahwa laki-laki memiliki resiko yang lebih tinggi untuk terkena obesitas dibandingkan pada wanita (Aranceta-Bartrina, Pérez-Rodrigo, AlberdiAresti, Ramos-Carrera, \& Lázaro-Masedo, 2016). Tujuan penelitian mengetahui hubungan obesitas sentral terhadap Kadar gula darah postprandial pada pegawai laki-laki dewasa di lingkungan kerja Universitas Lampung.

\section{METODE}

Metode yang digunakan adalah deskriptif analitik observasional kuantitatif dengan pendekatan cross sectional, dilaksanakan di Universitas Lampung, pada bulan SeptemberDesember 2017. Populasi pegawai laki-laki, sampel 65 orang dihitung berdasarkan rumus Lameshow, dengan kriteria inklusi dosen dan staf akademik usia 26-45 tahun, tidak memiliki riwayat penyakit diabetes melitus, tidak mengkonsumsi obat yang mempengaruhi kadar glukosa darah (metformin, glibenclamid), obat diet (mazindol, sibutramin, fentermin,orlistat), kortikosteroid (dexsametason, metilprednisolon, prednison), tidak menjalani program diet tertentu, tidak memiliki kebiasaan minum alkohol dan tidak ada tumor di sekitar pinggang dan panggul. Pengukuran lingkar pinggang dengan pita ukur presisi $0,1 \mathrm{~cm}$, dan pengukuran kadar glukosa darah dengan alat glukometer strip test. Analisis statistic berupa distribusi frekuensi berupa usia responden, kadar gula darah dan obesitas sentral, uji statistik yang digunakan adalah chi square.

Penelitian ini telah mendapatkan

Persetujuan Etik (Ethical Approval) No 3939/UN26.8/DL/2017 dari Komite Etik Penelitian Kesehatan Fakultas Kedokteran Universitas Lampung. 
HASIL

\section{Distribusi Frekuensi Usia Responden}

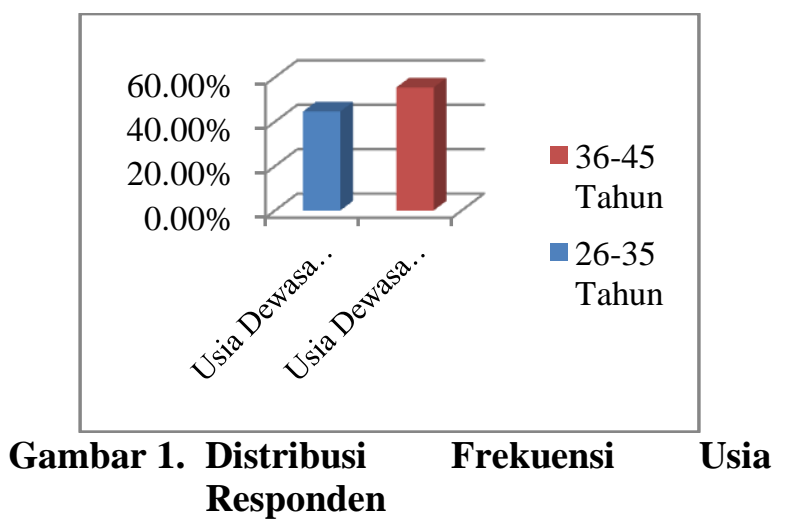

Berdasarkan gambar 1 diperoleh hasil terbanyak pada responden dengan rentang usia $36-45$ tahunsejumlah 36 orang $(55,4 \%)$ dan pada rentang usia 26-35 tahun sejumlah 29 orang $(44,6 \%)$.

\section{Distribusi Frekuensi Kadar Gula Darah Postprandial}

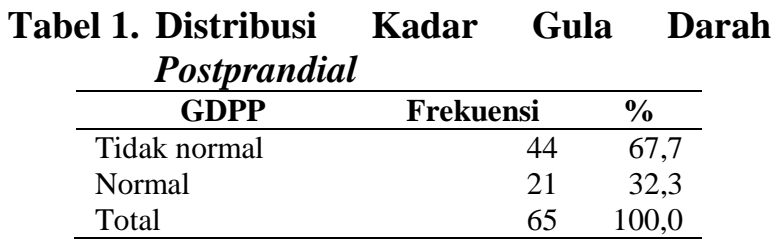

Kadar GDPP dibagi dalam dua kategorik yaitu kadar GDPP tidak normal jika hasil pemeriksaankadar gula darah $\geq 140 \mathrm{gr} / \mathrm{dl}$ dan kadar GDPP normal jika kadar gula darah $<140 \mathrm{gr} / \mathrm{dl}$. Hasil analisis menunjukkan bahwa responden dengan kadar GDPP tidak normal sebanyak 44 responden $(67,7 \%)$ dan responden dengan GDPP normal sejumlah 21 orang $(32,3 \%)$. Distribusi kadar gula darah postprandial dapat dilihat pada tabel 1 .

\section{Distribusi Frekuensi Obesitas Sentral}

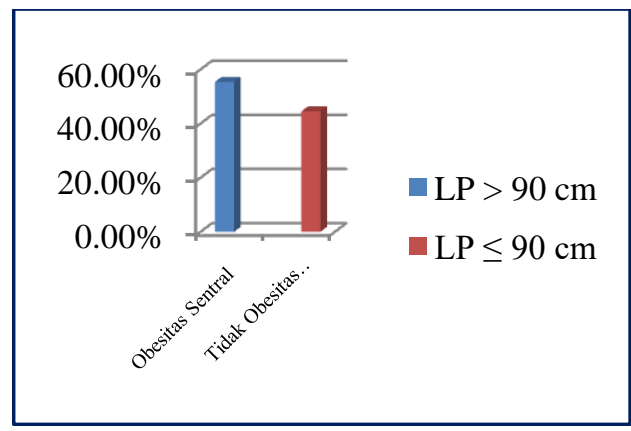

Gambar 2. $\begin{aligned} & \text { Hasil Pemeriksaan Lingkar } \\ & \text { Pinggang }\end{aligned}$
Status obesitas sentral responden dalam penelitian ini dibagi dalam dua kategorik yaitu obesitas sentral jika lingkar pinggang lebih dari $90 \mathrm{~cm}$, dan tidak obesitas sentral jika lingkar pinggang kurang sama dengan $90 \mathrm{~cm}$.Hasil penelitian menunjukkan bahwa distribusi frekuensi responden terbanyak adalah obesitas sentral sejumlah $36(55,4 \%)$. Sedangkan jumlah tidak obesitas sentral sejumlah 29 responden $(44,6 \%)$. Distribusi frekuensi obesitas sentral dapat dilihat pada gambar 2 .

Hubungan Obesitas Sentral terhadap Kadar Gula Darah Postprandial pada Laki-laki Dewasa di Lingkungan Kerja

Tabel 2. Hasil Uji Statistik Obesitas Sentral \& Kadar GDPP

\begin{tabular}{llllll}
\hline & \multicolumn{4}{c}{$\begin{array}{c}\text { Gula Darah } \\
\text { Postprandial }\end{array}$} & \multirow{2}{*}{ Nilai } \\
Sentral & $\begin{array}{c}\text { Tidak } \\
\text { normal }\end{array}$ & Normal & & $\boldsymbol{p}$ \\
& n & $\%$ & n & $\%$ & \\
\hline Ada & 31 & 86 & 5 & 14 & 0.001 \\
Tidak ada & 13 & 45 & 16 & 55 & \\
\hline
\end{tabular}

Hasil uji chi-square pada penelitian ini diperoleh adanya hubungan obesitas sentral terhadapkadar gula darah postprandial pada lakilaki dewasa di lingkungan kerja Universitas Lampung, dengan nilai $p$-value $=0,001$.

\section{PEMBAHASAN}

Obesitas didefinisikan sebagai kelebihan lemak atau jaringan adiposa didalam tubuh. Berdasarkan distribusi jaringan lemak obesitas sentral dapat dibedakan menjadi dua tipe yaitu obesitas android yang memiliki akumulasi lemak pada bagian atas tubuh dan obesitas ginekoid yang memiliki akumulasi lemak pada bagian bawah tubuh. Jika dibandingkan dengan obesitas ginekoid, obesitas android lebih sering dikaitkan dengan diabetes mellitus, penyakit jantung koroner, asam urat, dan batu ginjal (Soegondo S, 2014).

Berdasarkan data World Health Organization (WHO) pada tahun 2012 terdapat 1,6 miliar orang dewasa memiliki kecendrungan berat badan lebih (overweight) dan 400 juta diantaranya mengalami obesitas atau kegemukan. Epidemi obesitas yang meningkat mencerminkan adanya perubahan besar dalam masyarakat serta pola perilaku masyarakat dalam beberapa dekade terakhir. American Heart Association (AHA) mengemukakan bahwa pada tahun 2012 terdapat 154,7 juta orang dewasa di Amerika yang berusia 
20-74 tahun sebagai penyandang obesitas (BMI $>25$ ) yang terdiri dari 79,9 juta laki-laki dewasa dan 74,8 juta wanita dewasa (American Academy of Family Physician, 2013).

Seseorang dapat dikatakan obesitas melalui berbagai macam metode dan standar pengukuran distribusi lemak tubuh, salah satu cara adalah dengan metode pengukuran antropometrik. Antropometri merupakan salah satu metode untuk mengukur status gizi seseorang dan juga dapat digunakan sebagai screening obesitas, dan metode yang paling sering digunakan adalah BMI dan lingkar pinggang. Akan tetapi, dalam penilaian risiko, ukuran lingkar pinggang lebih reliabel ketimbang rasio lingkar pinggangpinggul. Selain IMT, salah satu parameter yang juga digunakan untuk menentukan obesitas adalah parameter antropometrik yakni ukuran lingkar pinggang (waist circumference), terdapat dua jenis obesitas, yaitu obesitas general dan obesitas sentral (Veghari, et al., 2016).

Indeks massa tubuh digunakan untuk mengukur obesitas general sedangkan ukuran lingkar pinggang digunakan untuk menghitung obesitas sentral. Seseorang dikatakan mempunyai obesitas sentral apabila mempunyai ukuran lingkar pinggang $\geq 90 \mathrm{~cm}$ bagi laki-laki Asia dan ukuran lingkar pinggang $\geq 80 \mathrm{~cm}$ bagi perempuan Asia..Pengukuranantropometri lingkar pinggang dilakukan dengan mengukur keliling perut melaluipertengahan krista iliaka dengan tulang iga terbawah secara horizontal (World Health Organization, 2008). Lingkar pinggang yang melebihi normal berhubungan dengan peningkatan kadar glukosa plasma melalui keseimbangan energi positif dari asupan energi yang berlebihan sehingga terjadi akumulasi lemak di jaringan adiposa abdominal yang berdampak pada peningkatan asam lemak bebas, proses glukogenesis, akumulasi trigliserida yang menyebabkan resistensi insulin (Jalal, 2008).

Banyak faktor yang mempengaruhi terjadinya obesitas, misalnya faktor genetik, faktor lingkungan, faktor kultural dan lain-lain. Masing-masing faktor mempunyai kontribusi yang berbeda-beda. Terdapat beberapa faktor yang dapat menyebabkan obesitas, diantaranya adalah faktor hormonal yang terdapat di dalam tubuh seperti leptin, insulin, kortisol, dan peptidausus. Leptin merupakan sitokin yang menyerupai polipeptida yangdihasilkan oleh adiposit yang bekerja melalui aktivasi reseptorhipotalamus. Injeksi leptin akan mengakibatkan penurunan jumlah makanan yang dikonsumsi. Insulin adalah anabolik hormon, telah diketahui bahwa insulin berhubungan langsung dalam penyimpanan dan penggunaan energi pada sel adiposa. Kortisoladalah glukokortikoid yang bekerja dalam mobilisasi asamlemak yang tersimpan pada trigliserida, hepatic glukoneogenesis, dan proteolisis (Fauci dan Longo, 2009). Faktor usia sangat diyakinkan menjadi pengaruh terbesar dari peningkatan prevalensi obesitas. Perubahan usia berkaitan dengan peningkatan distribusi jaringan lemak yang ditandai dengan meningkatnya ukuran lingkar pinggang seseorang.Semakin tua usia seseorang, maka resiko obesitas sentral pun semakin tinggi (Tchernof \& Després, 2013). Berdasarkan penelitian didapatkan hasil bahwa usia 35-54 tahun memiliki resiko lebih tinggi dibandingkan dengan usia 15-34 tahun, dan usia $\geq 55$ tahun memiliki resiko lebih tinggi dibandingkan dengan usia 35-35 tahun. Terdapat hubungan nyata positif antara umur dan kejadian obesitas sentral. Semakin meningkatnya usia, terjadi peningkatan kejadian obesitas sentral secara signifikan (Arianti \& Husna, 2015).

Asupan karbohidrat berlebih pada kelompok obesitas ditemukan lebih tinggi dibandingkan kelompok tidak obesitas. Tingginya konsumsi karbohidrat disebabkan sebagian sampel penelitian mengkonsumsi makanan tinggi karbohidrat pada jam istirahat (jajan) seperti nasi goreng, cilok, batagor, mie ayam, bakso, dan siomay. Selain itu juga dari jenis makanan ringan seperti chitato, keripik singkong, dan keripik kentang. Kelebihan karbohidrat di dalam tubuh akan diubah menjadi lemak. Perubahan ini terjadi di dalam hati. Lemak ini kemudian dibawa ke sel-sel lemak yang dapat menyimpan lemak dalam jumlah tidak terbatas. Ukuran atau porsi makan yang terlalu berlebihan juga dapat memiliki banyak kalori dalam jumlah banyak dibandingkan dengan apa yang dianjurkan untuk orang normal untuk konsumsi sehari-harinya (Kurdanti, et al., 2015).

Riwayat keluarga juga memiliki hubungan dengan kejadian obesitas sentral. Penelitian menunjukkan bahwa faktor riwayat keluarga/ genetik mempengaruhi besar IMT seseorang sebanyak $70 \%$. Faktor genetik berhubungan dengan variasi berat badan dan komposisi tubuh seseorang. Hasil penelitian menunjukkan adanya hubungan yang signifikan antara saudara atau pasangan yang obesitas dengan kejadian obesitas pada subjek. Faktor poligenik merupakan efek gen utama yang menghasilkan fenotip obesitas. Faktor genetik berpengaruh 25\%-75\% terhadap kejadian obesitas. Namun, terdapat faktor lain yang berpengaruh, yaitu pola asuh semasa anakanak serta adanya interaksi antara gen dengan lingkungan (Nisa dan Fikawati, 2013). Pada 
penelitian yang dilakukan oleh Marques sebelumnya telah dilaporkan bahwa obesitas meningkat pada usia 31-33 tahun. Prevalensi obesitas tertinggi terjadi pada wanita dengan usia 55-64 tahun $(28,0 \%$ untuk obesitas general, $73,4 \%$ untuk obesitas sentral) dan pada laki-laki dengan usia 45-54 tahun (34,7\% untuk obesitas sentral) (Marques-Vidal, et al., 2008).

Gula darah merupakan konsentrasi glukosa yang terkandung didalam darah. Untuk mengetahui kadar gula darah, terdapat beberapa waktu pemeriksaan kadar gula darah diantaranya adalah tes gula darah puasa, tes guladarah 2 jam setelah makan (postprandial), tes gula darah sewaktu dan tes toleransi glukosa. Tes gula darah puasa dilakukan dengan mengambil sampel darah sekurang-kurangnya delapan jam setelah makan, yaitu dalam keadaan perut kosong tetapi masih diperbolehkan untuk meminum air putih. Tes gula darah 2 jam setelah makan dilakukan setelah 2 jam mengkonsumsi makanan dengan porsi yang biasa dikonsumsi oleh responden (Fauci dan Longo, 2009).

Terdapat beberapa jenis pemeriksaan kadar gula darah yang bermanfaat dalam penilaian resistensi insulin yang kemungkinan terjadi pada kelompok obesitas yaitu pemeriksaan gula darah puasa dan pemeriksaan gula darah postprandial, yang dalam penelitian ini digunakan metode pemeriksaan kadar gula darah postprandial yang dilakukan 2 jam setelah makan. Kadar normal gula darah postprandial adalah $<140 \mathrm{~g} / \mathrm{dl}$ (Soegondo, 2014). Pada hati ditemukan bahwa transporter glukosa relatif tinggi dibandingkan dengan jaringan lain. Sifat transporter di hati berhubungan dengan sifat enzim di hati, glukokinase yang mengubah glukosa menjadi glukosa 6-fosfat. Sifat ini mendorong timbulnya fluks bersih glukosa ke dalam hati sewaktu konsentrasi glukosa darah meningkat setelah makan makanan tinggi karbohidrat dan efluks bersih glukosa keluar dari hati sewaktu konsentrasi glukosa menurun. Pada jaringan otot dan adiposa, transpor glukosa sangat dirangsang oleh insulin. Mekanisme yang berperan adalah pengerahan transporter glukosa dari vesikel intrasel ke dalam membran plasma. Di jaringan adiposa, perangsangan transpor glukosa menembus membran plasma oleh insulin menyebabkan peningkatan ketersediaan glukosa untuk sintesis asam lemak dan gliserol melalui jalur glikolitik. Di otot rangka, perangsangan transpor glukosa oleh insulin meningkatkan ketersediaan glikolisis dan sintesis glikogen (Murray, RK., Granner, DK., Mayes, PA., Rodwell, 2009)
Obesitas meningkatkan pengeluaran asam lemak bebas (free fatty acid) di darah. Pelepasan ini dapat mempengaruhi jaringan adiposa maupun jaringan non-adiposa, secara patofisiologi mempengaruhi berbagai macam organ seperti hepar dan pankreas. Asam lemak bebas yang dilepaskan secara berlebihan dari penyimpanan deposit triagliserol dapat menghambat lipogenesis, mencegah clearance tingkat serum triagliserol dan berkontribusi menyebabkan hipertrigliseridemia. Pelepasan asam lemak bebas oleh endotel lipoprotein lipase akibat peningkatan trigliserida serum meningkatkan elevasi lipoprotein $\beta$ sehingga menyebabkan lipolisis yang akan mengakibatkan terjadinya disfungsi reseptor insulin. Akibat dari resistensi insulin menyebabkan hiperglikemia akibat kompensasi glukoneogenesis di hati. Asam lemak bebas menurunkan utilisasi glukosa otot yang distimulasi insulin. Lipotoksisitas akibat jumlah asam lemak bebas yang meningkat menyebabkan penurunan sekresi insulin dari sel $\beta$ pankreas dan akhirnya menyebabkan kelelahan sel $\beta$ (Redinger, 2007).

Jenis penelitian yang dilakukan adalah deskriptif analitik dengan pendekatan crosssectional terhadap 65 pegawai laki-laki dewasa yang berumur 26-45 tahun. Teknik pengambilan sampel menggunakan teknik consecutive sampling. Kadar gula darah posprandial diukur dengan menggunakan alat glukometer dengan kapasitas pengukuran glukosa sampai $800 \mathrm{~g} / \mathrm{dl}$. Berdasarkan hasil penelitian dengan jumlah responden 65 orang diperoleh 36 orang mengalami obesitas sentral $(55,4 \%)$, dan sejumlah 44 orang dengan kadar glukosa darah postprandial yang tidak normal $(67,7)$. Hasil uji chi-square diperoleh nilai $p$-value sebesar 0,001 yang berarti bahwa Ho ditolak dan $\mathrm{H}_{1}$ diterima sehingga dapat disimpulkan bahwa terdapat hubungan obesitas sentral dengan kadar glukosa darah postprandial pada pegawai laki-laki dewasa di lingkungan kerja Universitas Lampung.

Hasil penelitian ini didukung penelitian Purwandari pada tahun 2014 dengan hasil $p$ value $=0,045$. Sedangkan nilai koefisien korelasi=0,319 yang menunjukan hubungan yang rendah dan berpola positif artinya semakin tinggi nilai indeks massa tubuh (obesitas) maka semakin tinggi kadar gula darahnya. Demikian juga dengan penelitian Justitia pada tahun 2012, tentang hubungan obesitas dengan peningkatan kadar gula darah pada guru SMP Negeri 3 Medan, diperoleh nilai $p$-value $=0,005$, disimpulkan peningkatan kadar gula darah dipengaruhi oleh obesitas berdasarkan persentase lemak tubuh. 
Penelitian Agrawal, et al pada tahun 2017 tentang Correlation between Body Mass Index (BMI) and Blood Glucose Levels in Jharkhand Population, menyatakan BMI sering kali dikaitkan dengan kadar gula darah. Penelitian pada 150 subjek yang terdiri dari 103 perempuan dan 47 laki-laki dengan hasil $p$-value $<0,001$ yang berarti terdapat hubungan anatara BMI yang tinggi dengan kadar gula darah puasa. Penelitian ini menyatakan bahwa terdapat korelasi yang positif antara BMI dan kadar gula darah, dan kadar gula darah seseorang akan meningkat seiring meningkatnya BMI. Orang yang lebih tua memiliki faktor resiko yang lebih tinggi terkait dengan meningkatnya kadar gula darah dan tekanan darah dibandingkan orang yang muda.

Hal ini sesuai dengan hasil penelitian terkait tentang hubungan obesitas dengan kadar glukosa darah, diantaranya penelitian yang dilakukan oleh Purwandari pada tahun 2014 menyatakan bahwa semakin tinggi nilai indeks massa tubuh maka semakin tinggi kadar gula darahnya dengan hasil $p$-value $=0,045$. Penelitian yang dilakukan oleh Justitia pada tahun 2012 tentang peningkatan kadar gula darah dipengaruhi oleh obesitas berdasarkan persentase lemak tubuh $p$-value $=0,005$. Penelitian yang dilakukan oleh Agrawal pada tahun 2017 tentang hubungan IMT dan kadar gula darah dengan hasil $p$-value $<0,001$ yang berarti terdapat hubungan anatara BMI yang tinggi dengan kadar gula darah (Agrawal, et al., 2017). Penelitian yang dilakukan oleh Putri tahun2015 tentang hubungan antara jenis obesitas dan kadar gula darah pada pegawai laki-laki dewasa memiliki hasil $p$ value $=0,001$. Penelitian yang dilakukan oleh Patil pada tahun 2012 di India menunjukan bahwa terdapat korelasi yang positif antara kadar gula darah puasa dengan obesitas dan lingkar pinggang dengan hasil p-value $<0.001$ (Patil, Sukumaran, Bhate, Mukherji, \& Chandrakar, 2012). Hasil penelitian yang dilakukan oleh Telles pada tahun 2018 menyatakan bahwa terdapat korelasi yang signifikan antara kadar gula darah puasa dengan lingkar pinggang dengan hasil $p$-value $<0.001$ dan $r=0.114$ (Telles, et al., 2018). Penelitian yang dilakukan oleh Rao pada tahun 2017 menyatakan bahwa variabel antropometrik seperti berat badan, lingkar pinggang, lingkar pinggul, rasio pinggangpinggul, rasio pinggang-tinggi dan indeks masa tubuh secara signifikan dipengaruhi oleh sedentary lifestyle dan pekerjaan yang kurang bergerak, menunjukkan bahwa profil kerja mempengaruhi indeks massa tubuh secara umum dan mengarah ke obesitas sentral dan general (Rao, Bhat, \& Bhatia, 2017).

Hasil penelitian ini memperkuat teori Guyton, yang menyatakan kegemukan merupakan faktor predisposisi untuk timbulnya peningkatan kadar gula darah, hal ini dikarenakan beberapa hal yaitu, sel-sel beta pulau Langerhans menjadi kurang peka terhadap rangsangan atau akibat naiknya kadar gula dan kegemukan juga akan menekan jumlah reseptor insulin pada selsel seluruh tubuh. Peranan obesitas dalam resistensi insulin dijelaskan dalam berbagai teori. Salah satu teori menyatakan bahwa jaringan lemak juga merupakan suatu jaringan "endokrin" aktif yang dapat berhubungan dengan hati dan otot yang merupakan dua jaringan sasaran insulin melalui pelepasan zat perantara yang nantinya mempengaruhi kerja insulin dan tingginya penumpukan jaringan lemak tersebut dapat berakhir dengan timbulnya resistensi insulin (Guyton \& Hall, 2012).

Resistensi insulin yang terjadi pada kelompok obesitas yang kemudian mengakibatkan penurunan kerja insulin pada jaringan sasaran sehingga menyebabkan glukosa sulit memasuki sel. Keadaan ini akan meningkatan kadar glukosa dalam darah. Peningkatan kadar glukosa darah yang terjadi dapat dideteksi dan diukur melalui pemeriksaan kadar gula darah.Kelebihan jaringan lemak (obesitas), keadaan yang makin sering dijumpai masyarakat modern juga dikaitkan dengan resistensi insulin dan diabetes (Abbas, 2015).

Obesitas sentral dapat meningkatkan terjadinya peningkatan kadar gula darah postprandial, untuk itu diperlukan adanya upaya preventif dan promotif untuk menurunkan berat badan ke arah ideal seperti perubahan gaya hidup tidak sehat (mengurangi jenis makanan yang mengandung karbohidrat dan glukosa, aktivitas fisik), melakukan edukasi terkait pengetahuan faktor risiko seperti genetik dan hormonal) dan faktor lain yang mempengaruhi.

\section{SIMPULAN}

Usia terbanyak berada pada rentang 36-45 tahun $(55,4 \%)$, gula darah $\geq 140 \mathrm{gr} / \mathrm{dl}$ sebanyak $67,7 \%$, dan lingkar pinggang $\geq 90 \mathrm{~cm}$ sejumlah $55,4 \%$. Terdapat hubungan obesitas sentral dengan kadar gula darah postprandial pada lakilaki dewasa di lingkungan kerja Universitas Lampung dengan nilai $p$-value $=0,001$. 


\section{DAFTAR PUSTAKA}

Abbas, A.K., Aster, J.C., dan Kumar, V. (2015). Buku Ajar Patologi Robbins. Edisi 9. Singapura: Elsevier Saunders.

Agrawal, N., Agrawal, M. K., Kumari, T., \& Kumar, S. (2017). Correlation between Body Mass Index and Blood Glucose Levels in Jharkhand Population, 4(8), 1633-1636.

American Academy of Family Physician. (2013). Diagnosis and Management of Obesity. (M. Adam Chrusch, Ed.). Philadelphia: American Academy of Family Physicians.

Aranceta-Bartrina, J., Pérez-Rodrigo, C., Alberdi-Aresti, G., Ramos-Carrera, N., \& Lázaro-Masedo, S. (2016). Prevalence of General Obesity and Abdominal Obesity in the Spanish Adult Population (Aged 25-64 Years) 2014-2015. Revista Española de Cardiología (English Edition), 69(6), 579587.

https://doi.org/10.1016/j.rec.2016.02.009

Arianti, I., \& Husna, C. A. (2018). Hubungan Lingkar Pinggang dengan Tekanan Darah Masyarakat di Wilayah Kerja Puskesmas Mon Geudong Tahun 2015. AVERROUS, 3(1), 56-69.

Fauci dan Longo. (2009). Harrison's Principle Of Internal Medicine (6th ed.). USA: The McGraw-Hill Companies Inc.

Guyton, A., \& Hall, J. (2012). Buku Ajar Fisiologi Kedoteran. Jakarta: EGC.

Jalal, F., Liputo, N. I., Susanti, N., \& Oenzil, F. (2009). Lingkar pinggang, kadar glukosa darah, trigliserida dan tekanan darah pada etnis Minang di Kabupaten Padang Pariaman, Sumatera Barat. Media Medika Indonesiana, 43(3), 129-136.

Justitia, N. L., 2012. Hubungan Obesitas dengan Peningkatan Kadar Gula Darah Pada GuruGuru SMP Negeri 3 Medan. [Skripsi]. Medan: Fakultas Kedokteran Universitas Sumatera Utara.

Kemenkes. (2013a). Riset Kesehatan Dasar. Jakarta: Badan Penelitian dan Pengembangan Kementrian Kesehatan RI.

Kemenkes. (2013b). Riset Kesehatan Dasar Lampung 2013. Jakarta: Badan Penelitian dan Pengembangan Kementrian Kesehatan RI.

Kurdanti, W., Suryani, I., Syamsiatun, N. H., Siwi, L. P., Adityanti, M. M., Mustikaningsih, D., \& Sholihah, K. I. (2015). Faktor-faktor yang mempengaruhi kejadian obesitas pada remaja. Jurnal Gizi Klinik Indonesia, 11(4), 179-190.
Long, M. D., Crandall, W. V., Leibowitz, I. H., Duffy, L., Del Rosario, F., Kim, S. C., ... Kappelman, M. D. (2011). Prevalence and epidemiology of overweight and obesity in children with inflammatory bowel disease. Inflammatory Bowel Diseases, 17(10), 2162-2168. https://doi.org/10.1002/ibd.21585

Marques-Vidal, P., Bochud, M., Mooser, V., Paccaud, F., Waeber, G., \& Vollenweider, P. (2008). Prevalence of obesity and abdominal obesity in the Lausanne population. BMC Public Health, 5(8), 330. https://doi.org/10.1186/1471-2458-8-330

Murray, RK., Granner, DK., Mayes, PA., Rodwell, V. (2009). Biokimia Harper (Edisi 25). Jakarta: EGC.

National Diabetes Information Clearing House. (2012). Epidemiology of Diabetes.

Nisa, K., \& Fikawati, S. (2013). Faktor Dominan yang Berhubungan dengan Obesitas Sentral pada Kader Kesehatan di Wilayah UPT Puskesmas Kecamatan Sawangan Kota Depok Tahun 2013. [Skripsi]. Depok: Universitas Indonesia.

Patil, S. P., Sukumaran, S., Bhate, A., Mukherji, A., \& Chandrakar, S. (2012). Correlation of blood sugar with waist circumference and body mass index in an Indian population. Glob J Pharm, 6(1), 8-11.

Purwandari, H. (2014). Hubungan obesitas dengan kadar gula darah pada karyawan di RS Tingkat IV Madiun. Jurnal Efektor, 25(1), 66.

Redinger, R. N. (2007). The Pathophysiology of Obesity and Its Clinical Manifestations, $3(11)$.

Rao, J., Bhat, A. N., \& Bhatia, A. S. (2017). Relationship of anthropometric variables with fasting blood sugar in moderate and sedentary workers. Int J Basic Appl Physiol, 6(1), 112.

Soegondo, S. (2014). Buku Ajar Ilmu Penyakit Dalam Jilid II. (S. Setiati, Ed.) (VI). Jakarta: Interna Publishing.

Soegondo S, G. R. (2014). Buku Ajar Ilmu Penyakit Dalam Jilid III. ( et al. Sudoyo AW, Setiyohadi B, Alwi I, Ed.) (V). Jakarta: Interna Publishing.

Tchernof, A., \& Després, J.-P. (2013). Pathophysiology of human visceral obesity: an update. Physiological Reviews, 93(1), 359-404. https://doi.org/10.1152/physrev.00033.201 1 
Telles, S., Pal, S., Sharma, S. K., Singh, A., Kala, N., \& Balkrishna, A. (2018). The association between the lipid profile and fasting blood glucose with weight related outcomes in healthy obese adults. $B M C$ Research Notes,

$1-4$. https://doi.org/10.1186/s13104-018-3485-4

Veghari, G., Sedaghat, M., Banihashem, S., Moharloei, P., Angizeh, A., Tazik, E., ... \& Honarvar, M. R. (2016). Prevalence of general, abdominal and waist-to-hip ratio obesity among adults in the north of Iran: an ethnical comparative study. Int $J$ Med
Res Health Sci, 5(1), 219-25.

Woerle, H. J. et al. (2007). Impact of fasting and postprandial glycemia on overall glycemic control in type 2 diabetes. Diabetes Research and Clinical Practice, 77(2), 280-285.

World Health Organization. (2008). Waist Circumference and Waist-Hip Ratio: Report of a WHO Expert Consultation. World Health Organization, (December), 8-11.

https://doi.org/10.1038/ejcn.2009.139. 